\title{
扁桃腺炎さ關節しロイマチスムス7 この關係に就て
}

\section{岡山醫科大學耳鼻咽㗋科教室(主任 田中教授)}

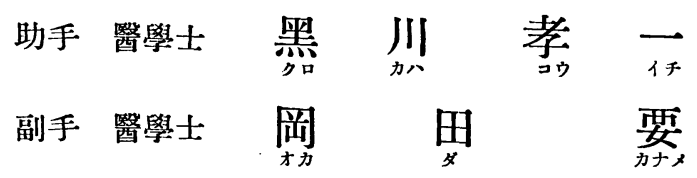

\section{緒言}

凡て扁桃眿炎が反復發來する場合，種々なる 疾患を併發する事あるは臨林上大いに注意すべ き事にして，急性絲毯體腎炎の大多數が扇桃腺 炎に原因を有する事は周知の所をるが, 關節し口 イマチスムス? \&亦屡々口峽炎に隨伴して發來 するものにして其の際口蓋扁桃腺が本症感染の 侵入門戸たるは腎㖪炎に對すると全く同樣の關 係にあり。

而して關節しロイマチスムスフの成因に關して は種及諭議さるる所なるが，其の際に於ける咽 頭所見は特飞本症發來機轉として治療上重要な る意味を有するにも拘らず, 往々之が看過され 此等關節炎の大多數は主として內科的に治療せ られ，吾々耳鼻咽喉科醫几揆らるる者は槨めて 尠し. 此處に述へんとする 3 例は最近余等の經 驗せる關節しロイマチスムスフと扁桃腺との關係 を明示する最も顯著なる症例にして關筙しロイ マチスムスフの成因及び治療に關して重大なる 指示を與ふるものと信じ，此處に發表して廣く 世の御批制を仰がんとす。

\section{症}

例

第 1 例 某 38 歲 女 主訴 習慣性しアンギーナフ 家族歷 特記すべき事無し。
既往歷 幼時より虚弱にして身體筑有惡く未だ月經 を見ず．昭和11年肺尖加答兒と診㡭されたる事あるも 暫くにして治痛せ $\boldsymbol{~}$.

現病歷 幼時上り風邪に罹り易く, 咽頭痛を度々來 たせり.13歲の顷某專門醫より兩側扁桃腺切除術を 2 问受け爾來咽頭痛を來たす事も無く經過せり．然るに 18歲頃下肢に腫脹を來し內科酱の診療を受けて脚氣な らんと云はれたる事あり． 又其顷より咽頭痛は輕度な るも屡々感目に罹り高熱を發する樣になれり．而して 28 歲の 6 月，始めて左肩の疼痛を來たし同年夏には兩 側滕關節の腫脹及び疼痛を來たしたり．以來32歳の12 月迄殆んど 3 日程を措いて滕關節，手關節及び指關節 に疼痛，䏦脹を來し，3，4日の經過を以て消退するを 常とせり．之等は常に感冒㥞症狀にして咽頭痛，發熱 に續いて來り，患者は殆んど林に就き居れる狀態なり。 治療としては內科醫より內服，注射を受け居りたり . 而して其後34歳頃よりは關節痛の發來回數莎くなり， 牦に3包乃至4间位の頻度となりたり．

然るに今年正月より咽頭痛を從來より激しく感ずる 樣になりたる篇某專門醫に治療を受け，同醫師より扁 桃腺摘出を獎められて本日當科を訪れ，田川敎授の診 察を受け關節しロイマチスムス7との關俰を說かれ手術 を受くる事となれり。

一般症狀 身長著しく小，一見小兒の如く骨格，策

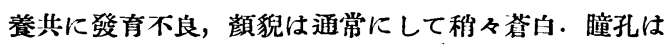
左右问大，對光反應迅速，結膜の允血は普通にして黃

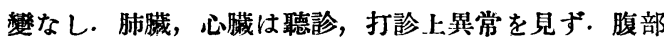

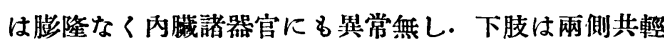
度に浮腫を示して筑简を殘し目膝蓋腱反射は缺如する も現在運動に際し疼痛無し.上肢は兩侧共指關節に輕 度の腫脹を來たせるも疼痛無く，文手及び肘關節に運 動異常無し. 其他肩部及び䁏部に疼痛無し. 
尿は淡黄色透明, 酸性.蛋白はしズルフォ・サリチルフ 酸試驗陽性，煮沸試驗陰性. 榶反應陰性.

局所所見 兩側鼓膜は特に戀化無く，德力正常な $\boldsymbol{~}$. 鼻孔は兩側中鼻道共に稍々荤狀變化を示し粘液の存在 を認む. 咽頭は雨側前口蓋弓に相等度の發赤あり、口 蓋扁桃腺は兩側共大にして腺窩搜大し右側のものには 2, 3の白き膿栓を認むるも, 現在器下痛其の他自舅症 狀無し. 舌扁桃腺も稍々大なり.喘頭所見には異常無 し. 又兩側頚部には小指頭大の淋巴腺を 2,3 触診し得 る8厭痛なし。

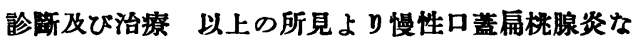
る事は明らかにして，且其の病歴よりして患者の最も 苦痛とする關節しロイマチスムスフも亦, 此處に其の因 を發するすのと考ふを得べし。

依つて此處に兩側口蓋扁桃腺摘出術を施行せ り. 雨 側扁桃腺共に脆く特に左側は瘾着强く, 其の下極は下 方舌扁桃腺汽續き居れり.されど出血比較的尠く順調 に手衕を終了せり. 而るに其後 4 日目に至りて $37,7^{\circ} \mathrm{C}$ に發熱し,兩側指關節に輕度の痛みを覺ゆるに至り6日 目には拇指を除く第 1 指骨と第 2 指骨間の關節㴧て 䏦脤, 疼痛を來し發熱又 $38,2^{\circ} \mathrm{C}$ K及ぶ. 然れども此の 症狀は 7日間の經過にて全く消退し，手術後12日目の 退院時には唯，尿に僅汃に蛋白の㕷加を殘し一般狀㦔 は至極良好となれり.

其の後 5ケ月後の10月下旬當科よりの乞ひに依り來 院・見るに榮䋏は特に變りたる事無けれど，手衍後は 感冒及び咽頭痛を來さず，唯䘕後 3ケ月目に僅に雨側 有の疼痛を來たせるのみにて其他の關節痛は全く發來 せず極めて愉快に生活し居るとの事なりき.

第 2 例 石田某 35 歳 男 (昭和14年 5 月 25 日初 衃)

\section{主訴 屡々反復せる扁桃腺炎}

家族歷 既往歷共に特記すいき事無し.

現病歷 4，5年前より風邪に䍜ると其の都度咽頭痛 あり.内科醫なる義兄を訪れ含嗽其の他の治療を受け たるが，其の時は扁桃腺炎に非ずと云はれたり．然る に3年前の夏の夜, 河に網打ちに行きてょり風邪に䍜り

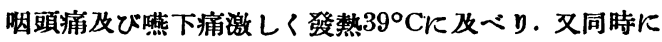
右側股關節に發赤, 腫脹を來し夜間は其の疼痛の篇に 睡眠不允分なりき・直ちに義兄(內科缼)を訪れしサリ チルフ酸劑の注射を受け 3 日後には治癋せり。其の後は 殆んど每月1回位風邪に罹り咽頭痛を來たすを同時に 全身の關節に疼痛を學え，義兄よりレサリチル酸劑の
注射を受けて治痹するを常とせり．偶ふ患者の弟が常 大學學生にして，田巾教授の臨猌講義を圗きて扁桃腺 と關節しロイマチスムスフとが密接なる關保にある事を

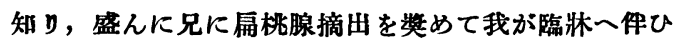
來りしものなり．現在發熱及び咽頭痛無し.

一般症狀 體格, 榮養共に中等度にして胸腹部臟器 下異常を認めず. 又現在全身の關節は自動的, 他動的 に運動可能にして發赤，腫脤等を認めず，尿檢查に於 て比重1010，蛋白，糖を證明せず.

局所所見 兩側口蓋扁桃腺は僅かに發赤せるも左程 肥大せず. 又腺䆟は稍々捾大せるる膿栓，義膜等を認 めず. 㯖器及び鼻啌に著變無し.

猃畩及び處置 多發性關節炎を件一る兩側慢性扁桃 腺炎として，雨側口蓋扁桃腺摘出を行へリ. 手術は雨 侧共に療着抄く且出血も少量にして順調に術を終れ y.

其の後の絓過術後 3 日目に左側足關節に疼痛及び 腫脹を來し，發熱 $37,8^{\circ} \mathrm{C}$ となりたり.更に術後 6 日 目には右側足關節に同様の苦痛を訴へたるむ服䒚する 事無くして治痖せ り．斯くして術後11日目退院.

然るに昨年末當科より其の後の經過を問ひ合せたる に, 患者は退院後は頗る元氣にて從來の如く頻々と風 邪に罹る事も無く，唯 1间のみ輕度の咽頭痛と共に關 節に疼痛を來たしたるす大した事は無く，從來の苦惱 は忘れし如き感ありとの音信ありたり。

第 3 例 高橋某 18 歳 男 (昭和15年3月18日初晾) 主訴 雯々綝返せる扁桃腺炎

家族歴 特記すべき事無し.

既往歷 6 歳の時某醫師より口蓋扁桃腺切除を受け し事あり. 其の後8 1 年に 2,3 回位咽頭痛ありて發熱 $40^{\circ} \mathrm{C}$ K及ぶを常とせり.

現病歴 13 歲の頃風邪に羅 $り$ て兩側股關節, 滕關節 及び足關節に疼痛及び灼熱感を來した り。爾來風邪を 反復するに從ひ咽頭痛を覺ゆると共に關節痛は手關節 及び頸部關節にも及ぶに至れり.依りて 3年前某內科 醫を訪れたるに輕度の肺尖浸潤あり，又關節痛に就い ては關節しロイマチスムスフと診断され菜劑を貪ひ服用 せり. 其の後暫くは經過良好なりしも寒冷に遭遇した り風邪に羅ると必ず咽頭痛及び關節痛ありて, 現在で は輕度の腰痛をも訴ふるに至れり，依りて餘りにも霆 々咽頭痛を綝返すを以て扁桃腺の微底的治療を求めて 來科し，口蓋扁桃腺摘出を獎められて郎日入院す。

一般症狀 體格, 策美共に中等度にして胸腹部臟器 
に著變を羿めず．現在全身の關第に疼痛，胝脹無きも 手關節を强く肧曲せしむれば刺度の疼痛あり．又第 5 胸椎に敲打痛及び輕度の原痛あり．頸部淋巴腺に腿脹 無し.

局所所見 兩侧口蓋扁桃腺は左、程肥大せず.腺简稍 く接大すれども膿栓を認めず. 何前口蓋弓に輕度の發 赤を認む.

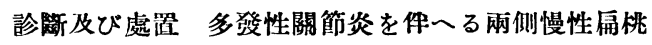
腺炎として兩側口蓋扁桃腺摘出を行ひたり. 手術は兩 側共に可成の癒着を認めたるも順調に術を終れり. 份 術後或は關節の疼痛を來たすや知れずと像告し置け り .

其の後の經過 果せる哉術後 3 日日より右侧㮏關節 に激烈なる㽝㖣ありて器法及びレザルッ・ブロカノンフ 注射を行へり. 倠熱39. $1^{\circ} \mathrm{C}$. 其の柆日は該關節痛は去 りたるも, 今度は左側㮏關節に，更に其の柆日は左右 手關筇等に疼痟を來たしたるが，日と共に其等の疼痟 は消退し術後13日目に退院せり.

本例は治療後山仯淺くして其の後常方より問合せを なす時甽に至らざりしも，5 月下旬先方よりの手紙に よれば其の後關䇻しロイマチスムスフの發來は一度も無 く，此の謌子なれば来仅は海本兵學校を受驗したしと 希望し居る旨急信ありたり。

\section{考按}

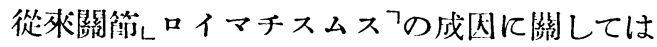

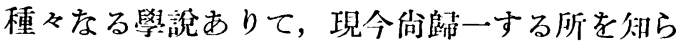
ざる祆態なり．本文の目的は本症の成泪の们た るかを說くに非ざれば簡單に之を維介せんに， 絒闻說，しアレルギーフ說，結核說等あり.

第一の絊菌說とは本症の成因は或種の細菌性

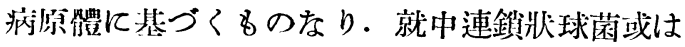
葡萄状球菌或は双球菌なりと主張する學者多く 本症患者の關第滲出液义は血液中より夫くの細 菌を證明し得たりと竬告せるも未だ一船學者の 承認を得るに至らず.

第二のしアレルギー一說とは本为は或種の抗原 に龄する生艠の特種の反應なりとなす學說な り.即ち或學者は本症は連領忋球菌を抗原とす
る個體の過飭性反應なりと云ひ，又他の學者は 本症は結核菌に因るムアレルギーフ反應なりと主 張し，其の外又抗原の種類を問はす或害作用に 對する生體のレアレルギーフ反應なりと說く學者 もゅり。

第三の結核說之は多數の症例に於て本症患者 の血液及び關節腟より結核菌を證明し, 且又本 症患者に於て高率に結核を證明せる事賽飞根據 を固くものなり。

份此の外體外的要約として寒冷, 濕潤を, 或 は內因的要約を重視する學者子あり.

以上述へし如く關箱し口イマチスムス?の成因 に就いては數多の研究業績あれどる，未だ之が 解決を見るに至らざる狀態にして，從つて其の 治療方針子亦塖趨に迷ふ所なしとせ和。例へば レサリチルフ酸劑或はレピラミドン娈內服により て著效を收め得たり之云ひ，或は溫泉㙩法，光 線療法等によりて好結果を得をり之云ふる，是 等は多くは一時的にして，斯かる袙法によりて

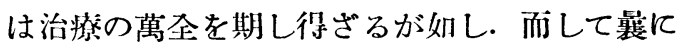
述へし余等の症例は僅か 3 例にして且扁桃腺摘 出後日向淺く後口の觀察に侯つべきも多し之 踓 女其の內第 1 例及び第 2 例の如きは術後 1 年を 經をるにる拘らす，此れ迄永らく苦惱したるが

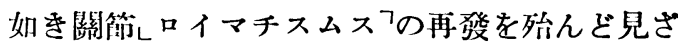
る事は注目に價する事と云ふべし。

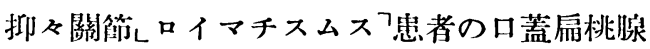
摘出を行ひて好結果を得をりといふふ塟告は，泰 西の交獻を繙けば屡々遭遇する所なり。例へば 1921年 Hasting は本症の 104例飞扁桃腺摘出を 行ひ多年の觀察の結果, 其の $39.5 \%$ 亿全治を見， 同じく39.5\%は輕快し，他は效果を認めざし と報告せり。文1922年Reuterは1910年より1920 
年に至る10年間に種くなる症狀によつて扁桃腺 摘出を行ひたる 500例 の經過を觀察せり．此の 內關節しロイマチスムスフに就いては急性症51例 中全治21例，輕快2例，不變3例，不明25例. 慢 性症20例中全治 3 例, 輕快 1 例, 不變 1 例, 不明 15 例といふ結果を得たりと報告せり．又最近の例 を擧ぐれば 1935年 Graham は關箼 ᄂロイマチ スムスフ患者の 438 例に扁桃腺摘出を行ひ, 其の 內300例は全治，100例は可成治痛，38例は不治 とレふ結果を得をり．但し不治の 38 例は上線 檢查によりて既に關節に變化の認められしもの なりしを附加せり．又 Kotyza は 1931 年より 1935年の間に2458例の患者に扁桃腺摘出を行ひ たる內，關節しロイマチスムスフは1140例あり しと云ひ，其の內特に慢性症に移行せさりりし即

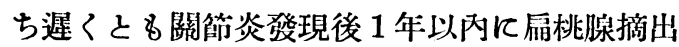
を行ひし100例に就いて其の後の經過を觀察せ るに，其の $94 \%$ が奎治或は輕快せりと報告せ b.

斯くの如く泰西文獻には數多の業䋶を見るに 搬らず，本邦にあつては關節 ᄂロイマチスム スフに扁桃腺摘出を行ひて好結果を得たりとの 報告は實に鉒々たるものにして，僅かに山中，

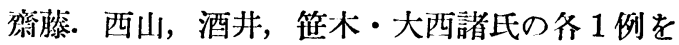
數ふるのみなり．此の事賽は本邦に於ては本症 が道接生命に危險なる族患に非ずとして放咀す るものの多き事にも因るべく，又假令䣽療を受 くるとも非として內科慗を訪れるもの多くして 本症を寺訴として斗鼻咽喉科を訪れる者は放ん ど稀なり、例へば余等の症例を猚みるに最近 1 年間に3例にして，第1例及び第 3 例は反䧗せる 扇䄻腺炎を主訴として某專門䣽より當科へ紹介
されたるもの及び直接當科を訪れたるものに， 偶々既往症に本症ありしを以て郎時扁桃腺摘出 を獎められたるものにして，第 2 例は田中敎授 の臨牀講義を聽きて始めて關節 レロイマチスム スフと扇桃腺とが密接なる關係にあるてとを知 りたる當大學生より扁桃腺摘出を獎められて當 科を訪れしものなり. 斯くの如く本症患者の我 が領域を訪れる事は極めて稀にして，餘程注意 せされば看過され勝ちな゙るものなり.

然れども2，3の本邦內科書を繙けば關節 し口 イマチスムスフは屢々遭遇する疾患なりと記戎 しある事よりしても，本症は本邦に於ては必ず しも稀有なる疾患に非ざる事を想像し得るもの にして, 又我が田中臨牀に於て最近 1 年間に 3 例の症例を得をる事よりしてる，吾タが本症よ 扁桃腺との關係に今後一首留意して口蓋扁桃腺 摘出を行はんか，更に多數の症例に遭遇し得る ならんと考ふるものなり。

裹に述へし如く病的扁桃腺が病原菌の侵入門 戸となり且又傳染源と化する事が一般に認めら るるに至りたる今日に於て, 又余等の 3 例に見 る如く扁桃腺摘出後總ての症例に於て關節に疼 痛を見て然る後に本症の治癒に至りたる點より しても，阴桃腺之本症之の間飞何等かの因果關 係のある事を推察するに充分にして，又假りに 內科的に䒚娈によりて一時的治癒を見るも本症 は必すしもてれを以て永久治癒洷るものとは 限らず，更に進みて心臟䇑膜症等の合併症を营 起する危險あるを虑かる時, 口蓋扁桃腺摘出に よりて病原菌の侵入門戶を除去するてとは意義 深き事と考へる次第なり。

以上を要するに余等の症例は關節 レロイマチ 
スムスフ患者にして扁桃腺に急性乃至慢性炎症 を認めたるものに，扁桃腺摘出を行ひて著效を 認めたるものにして, 總ての關節 レロイマチス ムスフに際して必ずしも之が全部扁桃腺炎に併 發せるものには非ずとするも，凡て本症に遭遇 したる場合一應扁桃腺の精細なる觀察を行ひ若 し炎症あらば口蓋扁桃腺摘出を試みる事は極め て效果ある療法なりと考へると共に，又他方扇
桃腺炎患者に遭遇したる際に若し的往症に本症 の經驗あれば，先づ口蓋扁桃腺摘出を行ひて其 の結果を觀察する事も亦適切なる療法なり之考 へ，茲に報告し臨牀諸家の御參考に供したる次 第なり.

㨔筆するに臨み御想切なる御指導並びに御校閵を賜 りし恩陃田巾敎授に深甚なる謝意を表す。

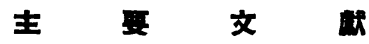

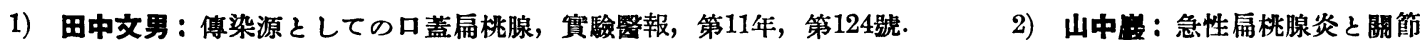
レロイマチスムスフとの關保に就いて, 耳鼻咽, 第1卷, 第5號. マチスフ の治驗, レグレンツ・ゲビートフ, 第6年, 第11號.

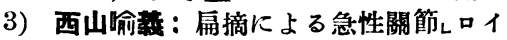
いて, 耳鼻咽, 第10卷, 第11號.

5) Hasting: Annals of Otology etc. Decemb. 1921.

Reuter: Erfahrungen bei 500 Tonsillektomien. Zeitschrift fuer Laryngologie. Bd. 10.1922. 7 7) Graham: The treatment of rheumatism. Annals of Otology 44. 1935. bei Rheumatismus(1937). Zentralb. fuer H.-N-u. Ohrenheilk. Bd. 29, 1938.

\section{所謂振子樣扁桃腺二症例}

京都帝國大學醫學部耳鼻咽喉科敎室 (主任 星野教授)

大學院學生 醫學士 川 $\prod_{\text {力口 }}$ 島 敏 行

\section{緒言}

口蓋扁桃腺より發生する有䓠性良性腫瘍とし て最も多きは纎維腫にして亞いで乳嘴腫, 脂肪 腫は極く稀有に屬す，之等良性腫瘍を一括して 廣義の振子樣扁桃腺之称する人あるも, 組織學 的檢索の結果は往々之等良性腫瘍の假面を被り 然も異型的扁桃腺肥大なることを設塄す，特に 乳嘴腫の形態をとれる異型的扁桃腺肥大の場合 多く，例へば1897年 Roberts が府桃腺乳嘴腫之 して報告せる症例に對し其後 Moure は之を乳 昆腫樣扁桃腺肥大なるへしし批制せるが如し. 余8亦口蓋扁桃腺より發生せる有莖性纎維腫な らんと思はるっ1例に遭遇し之を組織學的に檢 索したるに之亦扁桃腺の局所肥大に類似せるも
のなるてとを知り，且つその成立機轉に就き一 興を感じをるを以て，更に最近經驗せる典型的 なる所謂振子樣扁桃腺症例を共に合せて 2 例を 略述し榙䇡の御批制を仰がんとす.

\section{症例}

i) 患 者 根O, 17歳, 女子, 女小.

主 訴 口腔䏕瘍, 聴下腔碍.

家族杯並びに遗傳關保 特記すべきものなし.

既往症 生來强健にして時折風邪に䍜患する外著患 を知らず.

现病歷 約 2 䢙間前，風邪氣味にて時々輕き咳嗽を 示せるも發熱もなく 2,3 日にて輕快す. 然るに10日前 仰臥位のま〉蜜朴を食せる際，何等誘因るなく起れる

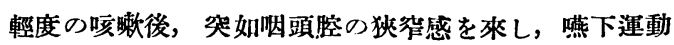

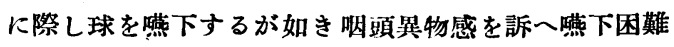

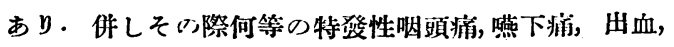

